\title{
Cell signalling of glucagon-like peptide- 1 action in rat skeletal muscle
}

\author{
A Acitores, N González, V Sancho, I Valverde and \\ M L Villanueva-Peñacarrillo
}

Department of Metabolism, Nutrition and Hormones, Fundación Jiménez Díaz, Avda Reyes Católicos 2, 28040-Madrid, Spain

(Requests for offprints should be addressed to M L Villanueva-Peñacarrillo; Email: mlvillanueva@fjd.es)

\begin{abstract}
Glucagon-like peptide-1 (GLP-1), an incretin with glucose-dependent insulinotropic and insulinindependent antidiabetic properties, has insulin-like effects on glucose metabolism in extrapancreatic tissues participating in overall glucose homeostasis. These effects are exerted through specific receptors not associated with cAMP, an inositol phosphoglycan being a possible second messenger. In rat hepatocytes, activation of phosphatidylinositol 3-kinase $(\mathrm{PI} 3 \mathrm{~K}) /$ protein kinase $\mathrm{B}(\mathrm{PKB})$, protein kinase $\mathrm{C}(\mathrm{PKC})$ and protein phosphatase 1 (PP-1) has been shown to be involved in the GLP-1-induced stimulation of glycogen synthase. We have investigated the role of enzymes known or suggested to mediate the actions of insulin in the GLP-1-induced increase in glycogen synthase $a$ activity in rat skeletal muscle strips.

We first explored the effect of GLP-1, compared with that of insulin, on the activation of PI3K, PKB, p70s6 kinase (p70s6k) and $\mathrm{p} 44 / 42$ mitogen-activated protein kinases (MAPKs) and the action of specific inhibitors of these kinases on the insulin- and GLP-1-induced increment in glycogen synthase $a$ activity.
\end{abstract}

The study showed that GLP-1, like insulin, activated PI3K/PKB, p70s6k and p44/42. Wortmannin (a PI3K inhibitor) reduced the stimulatory action of insulin on glycogen synthase $a$ activity and blocked that of GLP-1, rapamycin (a 70s6k inhibitor) did not affect the action of GLP-1 but abolished that of insulin, PD98059 (MAPK inhibitor) was ineffective on insulin but blocked the action of GLP-1, okadaic acid (a PP-2A inhibitor) and tumour necrosis factor- $\alpha$ (a PP-1 inhibitor) were both ineffective on GLP-1 but abolished the action of insulin, and Ro 31-8220 (an inhibitor of some PKC isoforms) reduced the effect of GLP-1 while completely preventing that of insulin.

It was concluded that activation of $\mathrm{PI} 3 \mathrm{~K} / \mathrm{PKB}$ and MAPKs is required for the GLP-1-induced increment in glycogen synthase $a$ activity, while PKC, although apparently participating, does not seem to play an essential role; unlike in insulin signaling, p70s6k, PP-1 and PP-2A do not seem to be needed in the action of GLP-1 upon glycogen synthase $a$ activity in rat muscle.

Journal of Endocrinology (2004) 180, 389-398

\section{Introduction}

Glucagon-like peptide-1 (GLP-1) is an insulinotropic peptide that has been proposed as a possible tool for the therapy of type 2 diabetes (Gutniak et al. 1992); it has incretin character and insulin-independent antidiabetic properties (Gutniak et al. 1992, D’Alessio et al. 1995), and mimics the effects of insulin on glucose metabolism in the skeletal muscle and liver from normal (Valverde et al. 1994, Villanueva-Peñacarrillo et al. 1994) and diabetic rats (Morales et al. 1997), and also in fat (Perea et al. 1997, Villanueva-Peñacarrillo et al. 2001a). In these extrapancreatic tissues, GLP-1 seems to act through specific receptors (Mérida et al. 1993, Valverde et al. 1993, Delgado et al. 1995, Villanueva-Peñacarrillo et al. 1995a,b, Yang et al. 1998) which, unlike the pancreatic one (Thorens 1992), are not associated with an activation of adenylate cyclase (Valverde et al. 1994, Villanueva-Peñacarrillo et al. 1994, Yang et al. 1998). It has been proposed that an inositol phosphoglycan (IPG) could be one of the possible second messengers in the actions of this peptide (Galera et al. 1996, Trapote et al. 1996, Márquez et al. 1998). In fact, a recent report has shown that GLP-1 stimulates glycogen synthase $a$ activity and glycogen synthesis in human skeletal muscle strips and primary culture myotubes, as does insulin, and that it fails to modify the cellular cAMP content while stimulating IPG generation (Luque et al. 2002). In addition, GLP-1 modulates glucose transport in cultured 3T3-L1 adipocytes (Wang et al. 1997), and it seems to control glucose transporter expression at the translational and/or post-translational level in tissues participating in overall glucose homeostasis in normal and 
diabetic rats (Villanueva-Peñacarrillo et al. 2001b). Insulin-like effects of GLP-1 have additionally been reported in mice abdominal muscle (O'Harte et al. 1997) and L6 myotubes (Yang et al. 1998), and in rat adipose tissue (Oben et al. 1991) and 3T3-L1 adipocytes (Egan et al. 1994).

Although some effects of GLP-1 in extrapancreatic tissues are well documented, the nature of its corresponding receptor is as yet unknown. Information about the cellular signalling of the action of GLP-1 has also been, for a long time, very scanty, it being reported only that GLP-1 activates p38 mitogen-activated protein kinase (MAPK), extracellular regulated kinases (ERKs) and phosphatidylinositol 3-kinase (PI3K) in insulinoma cells (Buteau et al. 1999, 2001) and in hamster ovary cells transfected with the pancreatic GLP-1 receptor (Montrose-Rafizadeh et al. 1999). Very recently, it has been shown that in rat hepatocytes the activation of $\mathrm{PI} 3 \mathrm{~K} /$ protein kinase $\mathrm{B}$ (PKB), protein kinase $\mathrm{C}(\mathrm{PKC})$ and protein phosphatase 1 (PP-1), but not PP-2A, seems to mediate the stimulatory action of GLP-1 on glycogen synthase $a$, while MAPKs and $\mathrm{p} 70 \mathrm{~s} 6$ kinase (p70s6k) could participate in other effects of GLP-1 (Redondo et al. 2003).

The entire itinerary and functional consequences of insulin signalling and glucose homeostasis are not available either. However, while a possible participation of p44/42 MAPKs remains unclear (Peak et al. 1998), solid data have demonstrated that binding of insulin to its receptor activates $\mathrm{PI} 3 \mathrm{~K}$, this enzyme producing phosphatidylinositol trisphosphate $\left(\mathrm{PIP}_{3}\right)$, which is considered a second messenger for insulin (Hajduch et al. 2001). $\mathrm{PIP}_{3}$ stimulates the phosphorylation and activation of $\mathrm{PKB}$ which has a number of substrates, one being glycogen synthase kinase 3 (GSK3) which is inactivated by phosphorylation (Cross et al. 1995). The inhibition of GSK3 could alter the balance between this enzyme and PP-1, leading to dephosphorylation of glycogen synthase and its subsequent activation. But, together with an implication of PKB in the stimulation of glucose uptake and glycogen synthesis by insulin (Ueki et al. 1998), it has been shown that direct inhibition of GSK3 in liver cells increases glycogenesis (Armstrong et al. 2001); thus, a combined mechanism of both might exist. In addition, some authors have provided evidence for a contribution of a rapamycin-sensitive signalling pathway, involving $\mathrm{p} 70 \mathrm{~s} 6 \mathrm{k}$, to the control of glycogen synthesis (Shepherd et al. 1995, Hurel et al. 1996). From results in human muscle cells, this pathway has been suggested to influence glycogenesis independently of GSK3 (Halse et al. 1999). In addition, it has been shown that insulin activates atypical PKC isoforms in a PI3K-dependent manner, and that activation of PKC as well as that of PKB is apparently required for insulininduced Glut-4 translocation and subsequent stimulation of glucose transport (Litherland et al. 2001).

Here we have studied in rat skeletal muscle the effect of GLP-1 on the activation of cellular enzymes known or proposed to mediate insulin actions, and their possible participation in the GLP-1-induced glycogen synthesis.

\section{Materials and Methods}

\section{Materials}

Human GLP-1 (7-36) amide (GLP-1; Bachem AG, Bubendorf, Switzerland); pork insulin (Novo Biolabs, Bagsvaerd, Denmark); ATP, $\left[\gamma^{32} \mathrm{P}\right]$ ATP $(30 \mathrm{Ci} / \mathrm{nmol})$, horseradish peroxidase-conjugated donkey anti-rabbit immunoglobulin, Rainbow markers, ECL-Western blotting kit and Hyperfilm ECL (Amersham Pharmacia Biotech, Amersham, Bucks, UK); rapamycin, wortmannin, okadaic acid, phosphatidylinositol and phosphatidylserine (Sigma Aldrich Quimica S.A., Madrid, Spain); tumor necrosis factor- $\alpha$ (TNF $\alpha$; Clontech Laboratories Inc., Palo Alto, CA, USA); PD98059 and Ro 31-8220 (Calbiochem, La Jolla, CA, USA); rabbit anti-total and anti-phosphorylated form of p44/42 MAP kinase, p70s6k and PKB (Cell Signalling Technology, New England Biolabs, Beverly, MA, USA); rabbit anti-PI3-kinase p85 (Upstate Biotechnology, Lake Placid, NY, USA). All other commonly used chemicals were from Sigma or Merck Pharma Quimica S.A. (Barcelona, Spain). Normal Wistar rats, kept on a standard pellet diet (UAR Panlab, Barcelona, Spain), were obtained from the animal breeding station of the Fundación Jiménez Díaz.

\section{General protocol}

Rats (248 $\pm 4 \mathrm{~g}, n=101)$ were killed by decapitation, and the soleus muscles were removed and divided into strips (two per muscle) which were individually attached by the tendon to a steel clip. For glycogen synthase a activity studies (Morales et al. 1997), the strips were preincubated for $60 \mathrm{~min}$ at $37^{\circ} \mathrm{C}$ in $1.5 \mathrm{ml}$ Krebs-Ringer bicarbonate (KRB) buffer containing 1\% bovine serum albumin (BSA) and $5 \mathrm{mM}$ D-glucose, and without or with $2.5 \times 10^{-5} \mathrm{M}$ PD98059 (a mitogen-activated protein kinase kinase (MEK) inhibitor), $10^{-6} \mathrm{M}$ wortmannin (a PI3K inhibitor), $10^{-7} \mathrm{M}$ rapamycin (a p70S6k inhibitor), $10^{-7} \mathrm{M}$ Ro 31-8220 (a PKC inhibitor), $10^{-6} \mathrm{M}$ okadaic acid (a PP-2A inhibitor) or $5 \times 10^{-8} \mathrm{M}$ TNFa (a PP-1 inhibitor). This was followed by a $10 \mathrm{~min}$ incubation at $37^{\circ} \mathrm{C}$ in the same medium as above, in the absence and presence of GLP-1 or insulin at $10^{-10} \mathrm{M}$ and $10^{-9} \mathrm{M}$ respectively, as these are the concentrations at which each hormone has previously been shown to exert maximal effect upon muscle glucose metabolism in vitro (VillanuevaPeñacarrillo et al. 1994, Luque et al. 2002). During preincubation and incubation, an atmosphere of $\mathrm{O}_{2} / \mathrm{CO}_{2}$ $(95 / 5)$ was maintained in the vial sealed with a rubber stopper. One of the muscle strips from each rat was always incubated in the absence of peptides as a paired control. 
The tissue samples were immediately homogenized in a medium containing $100 \mathrm{mM} \mathrm{NaF}, 35 \mathrm{mM}$ EDTA and $0 \cdot 5 \%$ glycogen $(\mathrm{w} / \mathrm{v})$ at $\mathrm{pH} 7 \cdot 4$, as already described (Villanueva-Peñacarrillo et al. 1994), and maintained at $-70{ }^{\circ} \mathrm{C}$ until the enzymatic activity was assayed.

In another group of experiments, meant to study MAPKs, PI3K, PKB or p70s6k enzyme activities, muscle strips were preincubated for $60 \mathrm{~min}$ in KRB with $1 \%$ BSA and $5 \mathrm{mM}$ D-glucose, followed by a 3 min incubation in the absence (control, one per rat) or presence of GLP-1 or insulin. Tissue samples were then homogenized at $4{ }^{\circ} \mathrm{C}$ in $1 \cdot 25 \%$ Triton X-100 containing $250 \mathrm{mM}$ sucrose, $20 \mathrm{mM}$ Tris/HCl, $2.5 \mathrm{mM} \mathrm{MgCl}_{2}, 50 \mathrm{mM} \beta$-mercaptoethanol, 1.2 mM EGTA, $1 \mathrm{mM} \quad \mathrm{Na}_{3} \mathrm{VO}_{4}, 5 \mathrm{mM} \quad \mathrm{Na}_{4} \mathrm{P}_{2} \mathrm{O}_{7}$, $50 \mathrm{mM} \mathrm{NaF}, 30 \mathrm{U} / \mathrm{ml}$ bacitracin, $2 \mu \mathrm{M}$ leupeptin, $2 \mu \mathrm{M}$ pepstatin, $\mathrm{pH} 7 \cdot 4$, and $2 \mathrm{mM}$ phenylmethylsulphonyl fluoride, then maintained at $4{ }^{\circ} \mathrm{C}$ for $30 \mathrm{~min}$, and finally centrifuged at $15000 \mathrm{~g}$ (Arnold et al. 1993). The supernatant (tissue lysate), containing cytosol and solubilized membranes, was kept at $-70{ }^{\circ} \mathrm{C}$ until needed. When dimethyl sulphoxide was required to dissolve some of the tested inhibitors, it was added in the same proportion to all experimental samples.

An aliquot volume was taken from all tissue lysate samples for protein content determination (Bradford 1976). Animal housing and protocols were approved by the Animal Use Committee of the Fundación Jiménez Díaz, Madrid, Spain.

\section{Glycogen synthase a}

The frozen tissue homogenates were thawed at $4{ }^{\circ} \mathrm{C}$ and their enzymatic activity was assayed, at least in duplicate, as the incorporation of UDP-glucose into glycogen, during $15 \mathrm{~min}$, as previously described in detail (VillanuevaPeñacarrillo et al. 1994). In each experimental rat, the mean value of the replicates corresponding to the muscle strip incubated in the absence of peptides or inhibitors was used as the control value.

\section{Immunoblotting}

Equal amounts of tissue lysates from each muscle sample were subjected to SDS-PAGE (Laemmli 1970), in parallel with molecular weight markers, on an $8 \%$ resolving gel. The separated proteins were then transferred to a nitrocellulose membrane in a semidry system (trans-blot SD semidry transfer cell; BioRad). For immunodetection, a Western blotting kit was used following the manufacturer's instructions, using total and phosphorylated p44/42 MAPK, PKB and $\mathrm{p} 70 \mathrm{~s} 6 \mathrm{k}$ respective antibodies, and a horseradish peroxidase-conjugated donkey anti-rabbit immunoglobulin second antibody, with detection by the enhanced chemiluminiscence method and quantitation by densitometric scanning of the autoradiography (Villanueva-Peñacarrillo et al. 2001a). In all experiments, the densitometric value of the band corresponding to the soleus muscle strip incubated in the absence of peptide was used as the control value.

\section{PI3K activity}

The enzyme activity was measured directly in p85 immunoprecipitates obtained by treating the muscle lysates with anti-PI3K p85 and subsequent coupling to protein A-agarose (Phung et al. 1997). The immunoprecipitates were incubated for $20 \mathrm{~min}$ at room temperature with $20 \mu \mathrm{M}\left[\gamma^{32} \mathrm{P}\right] \mathrm{ATP}(5 \mu \mathrm{Ci} / \mathrm{nmol})$ containing $6.25 \mathrm{mM}$ Hepes, $5 \mathrm{mM} \mathrm{MgCl}_{2}$ and $0.25 \mathrm{mM}$ EGTA, and in the presence of $0.25 \mathrm{mg} / \mathrm{ml}$ phosphatidylinositol/ phosphatidylserine as substrate. The reaction was interrupted by the addition of $400 \mu \mathrm{l}$ chloroform/methanol/ $\mathrm{HCl}$ (1:2:1, by vol), $150 \mu \mathrm{l}$ chloroform and $150 \mu \mathrm{l} \mathrm{HCl}$. After centrifugation $(10000 \boldsymbol{g})$, the organic phase was treated with an equal volume of methanol/100 mM HCl/ $2.5 \mathrm{mM}$ EDTA (1:1:1, by volume), and the new organic phase was separated by centrifugation and speed-vac dried. The lipidic extract, redissolved in chloroform, was spotted, together with $\mathrm{PIP}_{3}$ standard, on a silicagel TLC plate, and developed in $n$-propanol/acetic acid/ $\mathrm{H}_{2} \mathrm{O}$ (66:2:33, by vol). Plates were dried, and radioactive $\mathrm{PIP}_{3}$ was subsequently visualized by autoradiography and analyzed by densitometric scanning. In all experiments, the densitometric value of the band corresponding to the muscle strip incubated in the absence of peptide was used as the control value.

\section{Statistical study}

Results are expressed as means \pm S.E.M., together with the number of observations. The statistical significance $(P<0.05)$ of the increments was assessed by one-way ANOVA followed by the least significant differences (LSD) test for post-hoc multiple comparisons, using the Statistical Package for the Social Science software.

\section{Results}

\section{$P I 3 K / P K B$}

In rat soleus muscle, GLP-1, at $10^{-10} \mathrm{M}$, induced a significant increase in the PI3K activity - with respect to the control value obtained in one or two muscle strips from each experimental rat, incubated in the absence of peptide, measured after a $3 \mathrm{~min}$ incubation (Fig. 1). As expected, $10^{-9} \mathrm{M}$ insulin also stimulated the PI3K activity, the magnitude of the increment in the generation of $\mathrm{PIP}_{3}$ being apparently the same as that obtained with $10^{-10} \mathrm{M}$ GLP-1.

In another group of rats, GLP-1, like insulin, also significantly stimulated the phosphorylation of PKB, the 

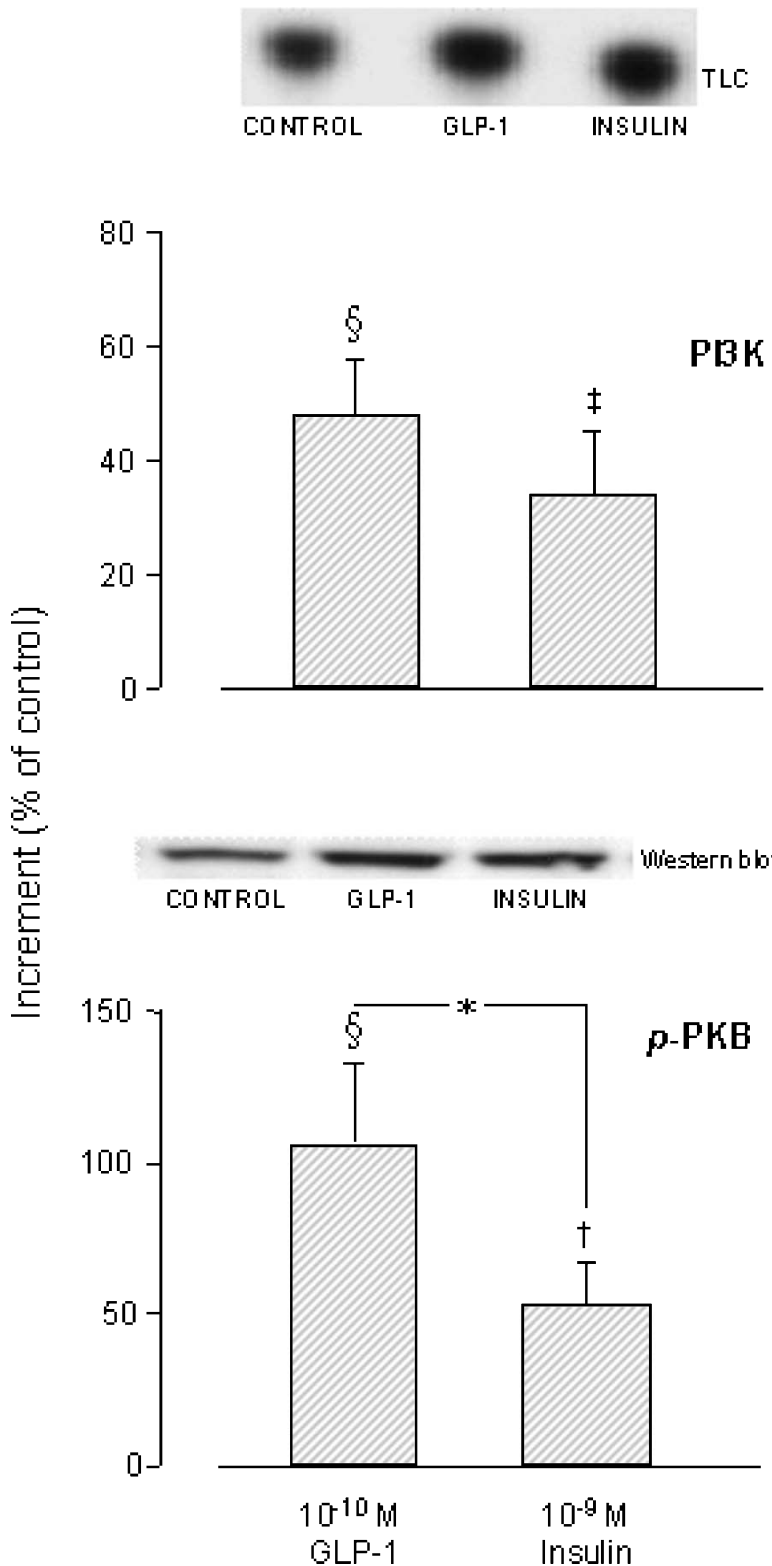

Figure 1 Effect of $10^{-10} \mathrm{M} \mathrm{GLP}-1$ and $10^{-9} \mathrm{M}$ insulin (representative blots and means \pm S.E.M., $n=4-5$ rats) upon PI3K activity and PKB phosphorylation ( $p)$, in soleus muscle strips incubated for $3 \mathrm{~min}$. Values are relative to the respective paired control obtained in the muscle sample incubated in the absence of peptide. LSD test: ${ }^{\star} P=0 \cdot 024,+P=0 \cdot 012, \ddagger P=0 \cdot 001, \S P<0 \cdot 0001$.

increment induced by $10^{-10} \mathrm{M}$ GLP-1 being higher than that exerted by $10^{-9} \mathrm{M}$ insulin (Fig. 1).

\section{$p 70 s 6 k$}

Figure 2 shows the effect of GLP-1 and that of insulin on p70s6k activity in rat soleus muscle, after a 3 min incubation. GLP-1, at $10^{-10} \mathrm{M}$, induced a significant increase
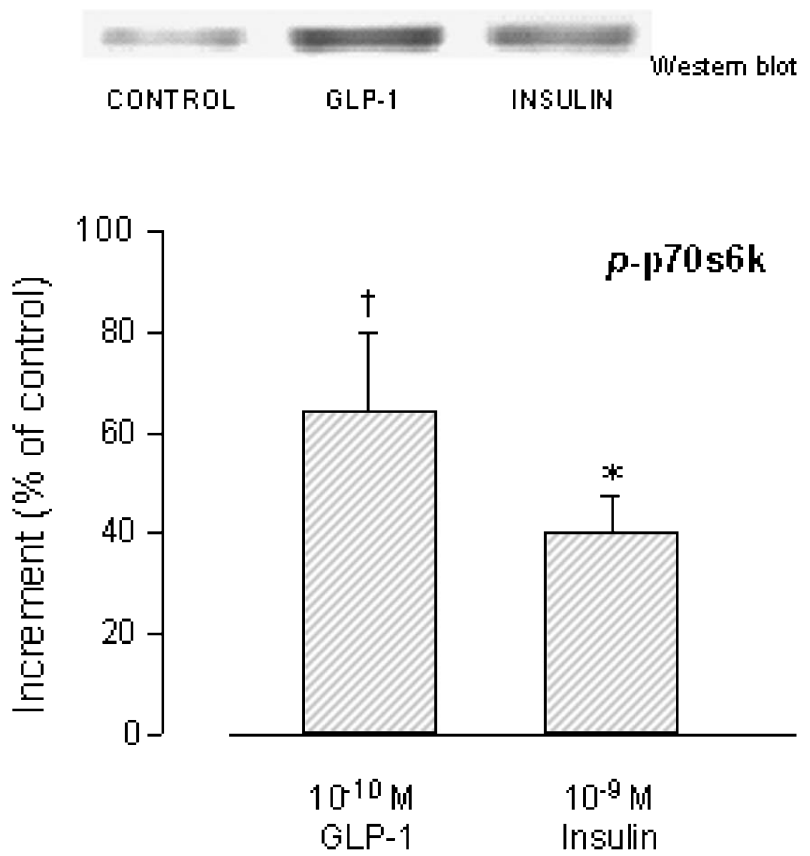

Figure 2 Effect of $10^{-10} \mathrm{M}$ GLP-1 and $10^{-9} \mathrm{M}$ insulin upon p70s6k phosphorylation (representative blot and means \pm S.E.M., $n=4-6$ rats), in soleus muscle strips incubated for $3 \mathrm{~min}$. Values are relative to the respective paired control obtained in the muscle sample incubated in the absence of peptide. LSD test: ${ }^{*} P=0.032$, $\dagger P=0 \cdot 001$.

in the phosphorylation of the enzyme, similar in magnitude to that exerted by $10^{-9} \mathrm{M}$ insulin - with respect to the control value obtained in one or two muscle strips from each experimental rat, incubated in the absence of peptide.

p42/44 MAPKs

Figure 3 shows the action of GLP-1 and that of insulin on p44 and p42 MAPKs activity, in rat soleus muscle after a 3-min incubation. At $10^{-10} \mathrm{M}$, GLP-1 significantly induced the phosphorylation of both p44 and p42 fractions - with respect to the control value obtained in one or two muscle strips from each experimental rat, incubated in the absence of peptide. The magnitude of this effect of GLP-1 on both MAPKs was statistically indistinguishable from those exerted by $10^{-9} \mathrm{M}$ insulin.

\section{Glycogen synthase a activation}

Figure 4 shows the effect of wortmannin, rapamycin and PD98059 - considered inhibitors of PI3K, p70s6k and MAPK cellular enzymes respectively - upon the increasing action of $10^{-10} \mathrm{M}$ GLP-1 and $10^{-9} \mathrm{M}$ insulin on glycogen synthase a activity in rat muscle strips. As expected, and in the three groups of experiments shown, GLP-1, as well as insulin, induced a significant stimulation 

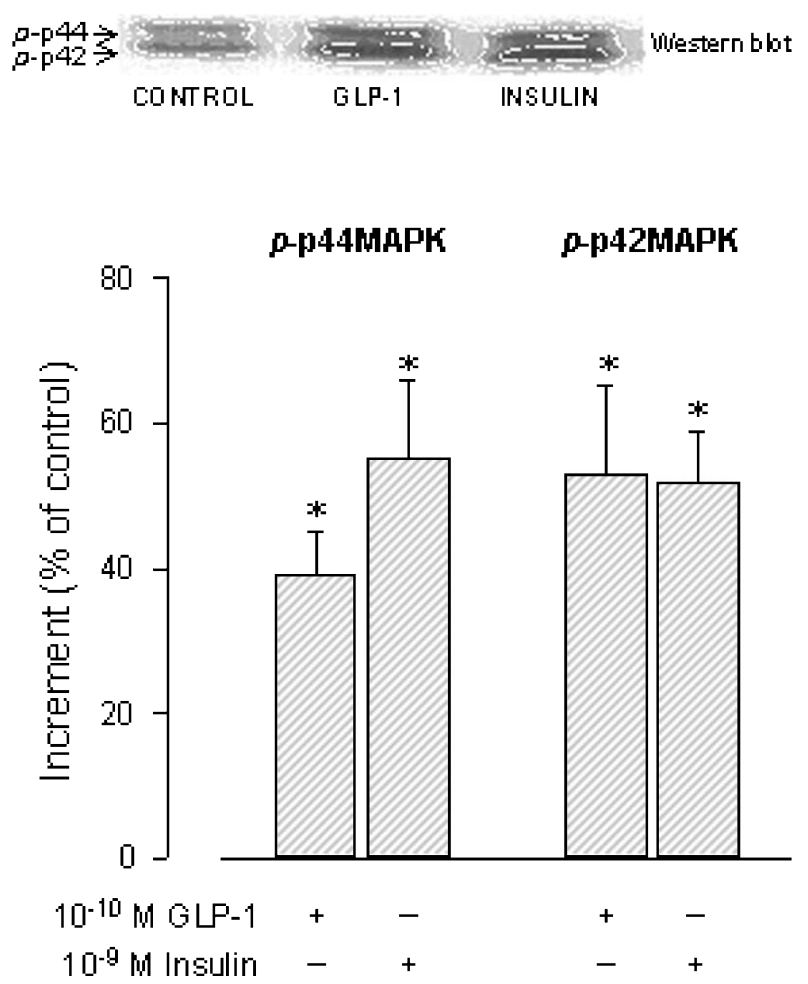

Figure 3 Effect of $10^{-10} \mathrm{M}$ GLP-1 and $10^{-9} \mathrm{M}$ insulin upon phosphorylation of p44 and p42 MAPKs (representative blot and means \pm S.E.M. $n=4-5$ rats), in soleus muscle strips incubated for $3 \mathrm{~min}$. Values are relative to the respective paired control obtained in the muscle sample incubated in the absence of peptide. LSD test: ${ }^{*} P<0 \cdot 0001$.

of the enzyme activity, relative to the respective control value obtained in muscle samples incubated in the absence of peptides or inhibitors. The presence of wortmannin dramatically reduced the increase in the glycogen enzyme stimulation exerted by GLP-1, to values even below that of the control $(3.23 \pm 0.02 \mathrm{mU} / \mathrm{g}$ protein, $n=9$ rats $)$, and indistinguishable from that in muscle samples incubated in the sole presence of the inhibitor. Although wortmannin also significantly diminished the insulin-induced stimulation of the enzyme activity, a remaining effect slightly above that of the control was still measured. When p70s6k activity was inhibited by treating the muscle with rapamycin, a drastic reduction of the insulin-induced increase in the activity of glycogen synthase a occurred (control: $2 \cdot 07 \pm 0.02 \mathrm{mU} / \mathrm{g}$ protein, $n=12 \mathrm{rats})$, while that exerted by GLP-1 was not modified. The presence of PD98059 prevented the GLP-1-induced stimulation of the glycogen enzyme activity (control: $2.73 \pm 0.03 \mathrm{mU} / \mathrm{g}$ protein, $n=10$ rats), but attenuated that of insulin. While the sole presence of rapamycin or PD98059 did not apparently modify the control value, a modest inhibitory effect, although not statistically significant, was measured with wortmannin.
Inhibition of PP-2A activity by okadaic acid treatment (Fig. 5), or that of PP-1 by TNFa, did not modify the GLP-1-induced increment in muscle glycogen synthase $a$ activity. Both though reduced that exerted by insulin to similar values to those induced by the respective inhibitor alone, which were apparently lower, particularly in the case of okadaic acid, than that of the corresponding control (control PP-2A: $2 \cdot 50 \pm 0.03 \mathrm{mU} / \mathrm{g}$ protein, $n=12$ rats; control PP-1: $2.73 \pm 0.03 \mathrm{mU} / \mathrm{g}$ protein, $n=8$ rats). When Ro 31-8220 (Fig. 6), a PKC inhibitor, was present, a drastic reduction in the insulin-induced increment of glycogen synthase a activity was detected, to a value significantly below the control $(1.70 \pm 0.03 \mathrm{mU} / \mathrm{g}$ protein, $n=14$ rats), and similar to that obtained in the sole presence of the inhibitor. The GLP-1-induced increment in the enzyme activity, which in this group of rats was apparently higher than that exerted by insulin, was partially diminished in muscles treated with Ro 31-8220.

\section{Discussion}

We document in this study that GLP-1 activated PI3K/ $\mathrm{PKB}, \mathrm{p} 70 \mathrm{~s} 6 \mathrm{k}$ and $\mathrm{p} 42$ and $\mathrm{p} 44$ MAPKs in normal rat soleus muscle, as it does in freshly isolated rat hepatocytes (Redondo et al. 2003), and like the action of insulin in rat hepatocytes (Peak et al. 1998) and human myoblasts (Hurel et al. 1996).

The stimulatory action of GLP-1 upon muscle glycogen synthase $a$ activity was greatly reduced by wortmannin, but not by rapamycin, as occurs in rat hepatocytes (Redondo et al. 2003), indicating that activation of PI3K, but not that of p70s6k, is crucial in the action of GLP-1 in these two tissues. The presence of wortmannin also significantly reduced the stimulatory action of insulin, but unlike GLP-1, and as occurs in rat hepatocytes (Redondo et al. 2003), rapamycin prevented the stimulatory effect of insulin upon the muscle glycogen enzyme. An inhibitory action of wortmannin in the insulin-induced increase in glycogen synthase $a$ activity has already been reported in human myoblasts, in which it was also shown that stimulation of the enzyme by insulin was attenuated by rapamycin (Hurel et al. 1996), suggesting that p70s6k could be participating, perhaps not in the initial stimulation of the glycogen enzyme by insulin, but possibly in its maintenance. While some studies in rat hepatocytes have concluded that there is no participation of a rapamycin-sensitive pathway in the control of glycogen synthesis by insulin (Peak et al. 1998), others have implicated p70s6k in the rat diaphragm (Azpiazu et al. 1996) and also in 3T3-L1 adipocytes (Shepherd et al. 1995) but not in rat adipocytes (Moule et al. 1995), indicating tissue differences in the insulin-signalling pathways.

Unlike previous observations in rat hepatocytes, in which inhibition of MEK/MAPKs did not affect the GLP-1-induced stimulation of glycogen synthase $a$ activity 

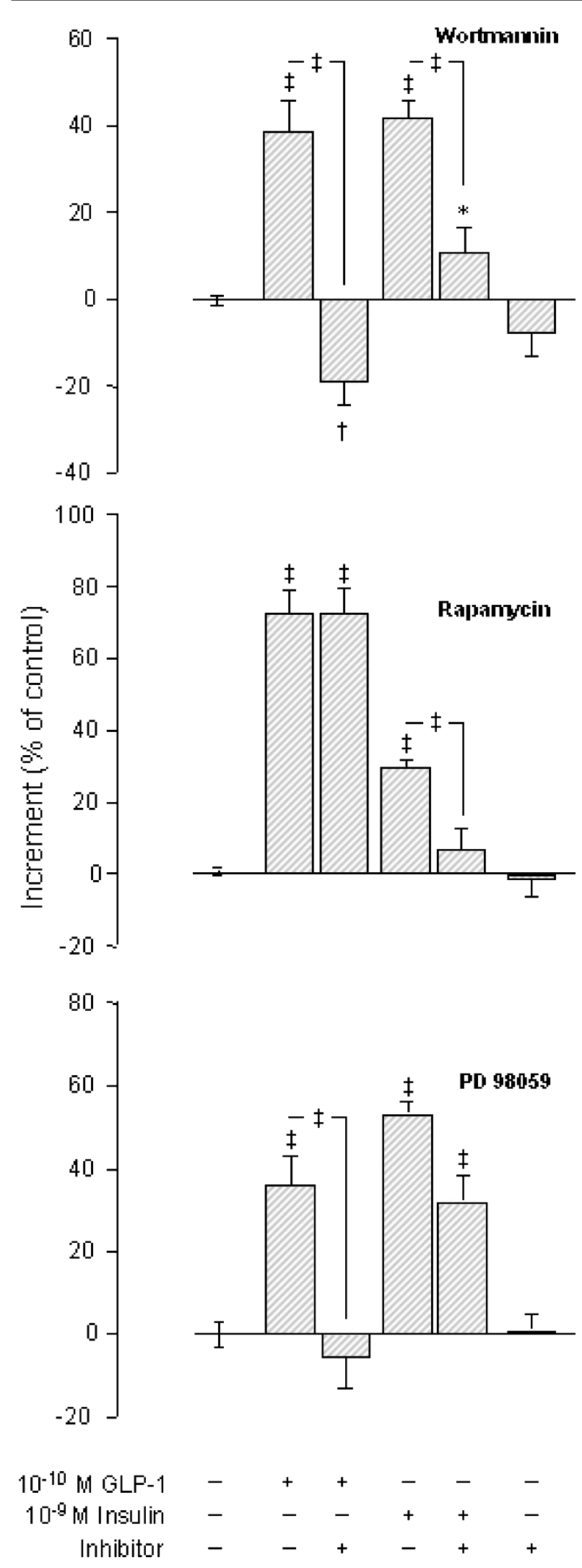

Figure 4 Glycogen synthase a activity in rat soleus muscle strips incubated for $10 \mathrm{~min}$ in the absence and presence of $10^{-10} \mathrm{M}$ GLP-1 or $10^{-9} \mathrm{M}$ insulin, and without and with $10^{-6} \mathrm{M}$

wortmannin, $10^{-7} \mathrm{M}$ rapamycin or $2.5 \times 10^{-5} \mathrm{M}$ PD98059. Values (means \pm S.E.M., $n=4-7$ rats) are relative to the respective paired control obtained in the muscle sample incubated in the absence of both peptide and inhibitor $(2.78 \pm 0.02 \mathrm{mU} / \mathrm{g}$ protein, $n=31$ rats). LSD test: ${ }^{*} P=0 \cdot 038,+P=0 \cdot 002, \neq P<0 \cdot 0001$. 


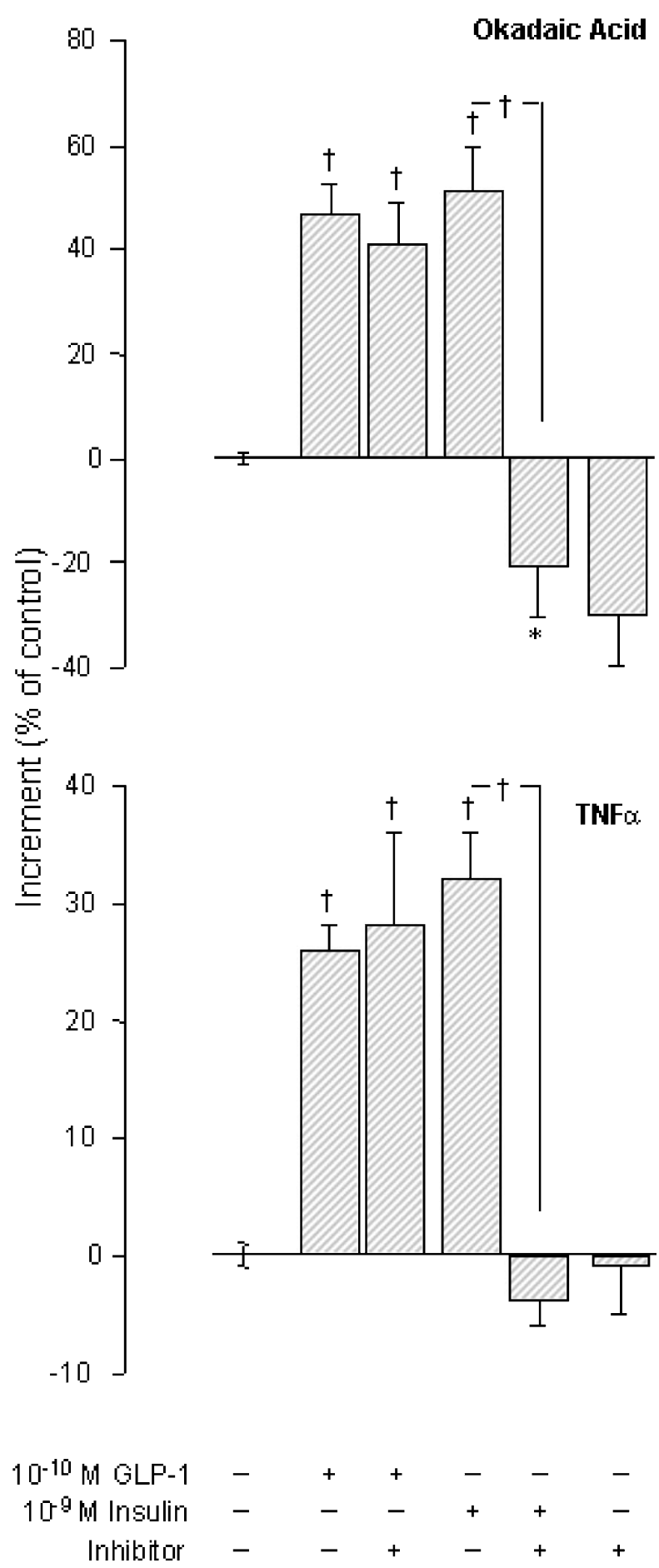

Figure 5 Glycogen synthase a activity in rat soleus muscle strips incubated for $10 \mathrm{~min}$ in the absence and presence of $10^{-10} \mathrm{M}$ GLP-1 or $10^{-9} \mathrm{M}$ insulin, and without and with $10^{-7} \mathrm{M}$ okadaic acid or $5 \times 10^{-9}$ M TNF $\alpha$. Values (means \pm S.E.M., $n=3-6$ rats) are relative to the respective paired control obtained in the muscle sample incubated in the absence of both peptide and inhibitor $\left(2.59 \pm 0.02 \mathrm{mU} / \mathrm{g}\right.$ protein, $n=20$ rats). LSD test: ${ }^{*} P=0.021$, $+P<0 \cdot 0001$.

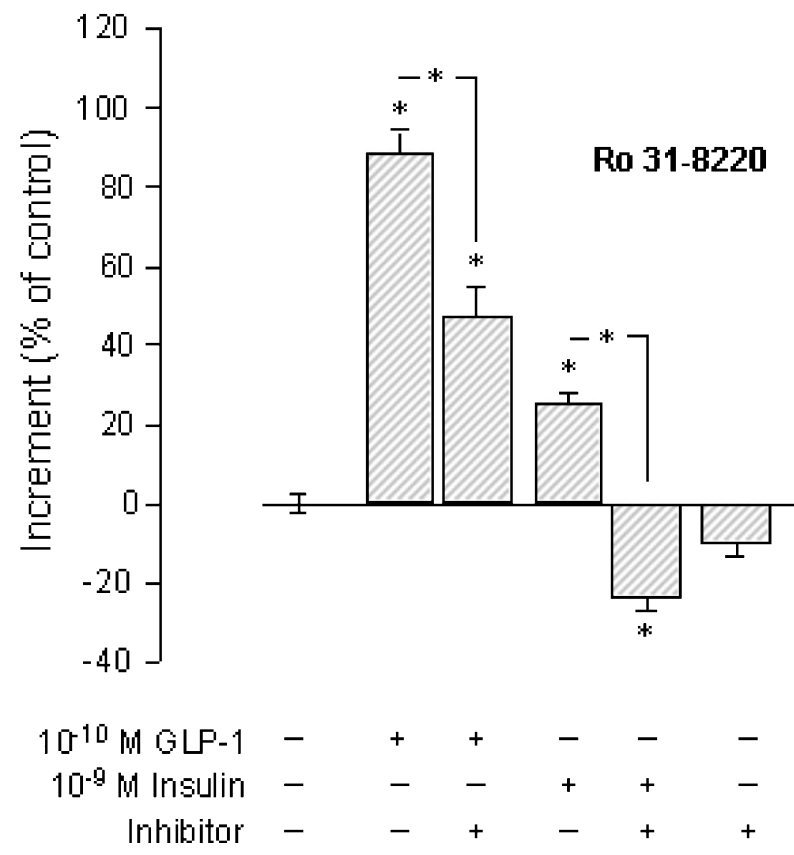

Figure 6 Glycogen synthase a activity in rat soleus muscle strips incubated for $10 \mathrm{~min}$ in the absence or presence of $10^{-10} \mathrm{M}$ GLP-1 or $10^{-9} \mathrm{M}$ insulin, and without and with $10^{-7} \mathrm{M}$ Ro 31-8220. Values (means \pm S.E.M., $n=7$ rats) are relative to the respective paired control obtained in the muscle sample incubated in the absence of both peptide and inhibitor $(1.70 \pm 0.03 \mathrm{mU} / \mathrm{g}$ protein, $n=14$ rats). LSD test: ${ }^{*} P<0 \cdot 0001$.

synthase activation by insulin in 3T3-L1 adipocytes (Brady et al. 1997). Nevertheless, and in relation to the Ser/Thr phosphatase PP-1, our data are in agreement with previous observations in rat muscle and adipose tissue (Ragolia \& Begum 1998), from which it was additionally proposed that insulin regulates the activity of $\mathrm{PP}-1$ through a complex cell-specific mechanism that would involve the $\mathrm{PKC} / \mathrm{PI} 3 \mathrm{~K} / \mathrm{PKB}$ cascade - with a resultant inhibition of GSK-3 and consequent activation of glycogen synthase, and/or that of ras/MAPKs (Liu \& Brautigan 2000); this, despite the fact that results in ovary cells overexpressing insulin receptor made somehow questionable the possibility that PP-1 is required for full activation of the glycogen enzyme by insulin (Liu \& Brautigan 2000).

PKC is one of the two Ser/Thr kinases known so far to act downstream from PI3K, PKB being the other; in fact, the atypical PKC isoform $\zeta$ has been shown to be activated by the poly-phosphoinositides accumulated in insulintreated cells, and it has been shown that this kinase is sensitive to PI3K inhibitors such as wortmannin. Also, it has been reported that activation of PKC $\zeta$ or PKC $\lambda$ induces Glut-4 translocation (Pessin \& Saltiel 2000), and that several PKC isoforms are chronically activated in human and animal models of insulin resistance (Considine et al. 1995, Avignon et al. 1996, Ishizuka et al. 1998). In addition, PKC has been implicated in the phosphorylation 
of GSK-3 and subsequent activation of glycogen synthase $a$ in isolated hepatocytes (Pugazhenthi \& Khandelwal 1995). In the present study, by using Ro 31-8220, a staurosporine derivative and potent bisindolylmaleimide inhibitor of several PKC isoforms - mainly $\alpha, \beta_{1}, \beta_{11}, \gamma$ and $\varepsilon$ (Wilkinson et al. 1993), a moderate, although significant, inhibition of the GLP-1-induced increase in glycogen-synthase a activity was detected, as previously observed in rat hepatocytes (Redondo et al. 2003). However, the presence of the inhibitor completely blocked the action of insulin in the skeletal muscle, unlike in rat liver cells (Redondo et al. 2003), where the stimulatory effect of insulin upon the glycogen enzyme was not apparently modified. Although the present data suggest that PKC might have a role in this action of GLP-1 in the skeletal muscle, no further conclusion can be stated as Ro 318220 is not highly selective for any of the different PKC isoenzymes. In fact, the majority of the inhibitors available for the moment, some of them used in this study, could affect more than one protein kinase (Davies et al. 2000).

Taking all these factors into consideration, we propose that the stimulatory action of GLP-1 on glycogen synthase $a$ in rat skeletal muscle seems to occur through a cellular signalling pathway that would involve $\mathrm{PI} 3 \mathrm{~K} / \mathrm{PKB}$, MAPKs and perhaps partially $\mathrm{PKC}$, but not the protein phosphatases PP-1 and PP-2A, and as GLP-1 activates the phosphorylation of $\mathrm{p} 70 \mathrm{~s} 6 \mathrm{k}$, this kinase could be participating in other effects of GLP-1 in the muscle.

\section{Acknowledgements}

This work was supported by grants from the Ministerio de Educación y Cultura (PM 99/0076 and SAF 2002/ 00938), Spain. We thank Estrella Martín-Crespo for excellent technical assistance and Mark Davis for proof reading the manuscript. A A, N G and V S are Research fellows from the Fundación Conchita Rabago de Jiménez Díaz.

\section{References}

Armstrong JL, Bonavaud SM, Toole BJ \& Yeaman SJ 2001 Regulation of glycogen synthesis by amino acids in cultured human muscle cells. Journal of Biological Chemistry 276 952-956.

Arnold TP, Stadaert ML, Hernandez H, Watson J, Mischak H, Kazanietz MG, Zhao L, Cooper DR \& Farese RV 1993 Effects of insulin and phorbol esters on MARCKS (myristoylated alanine-rich C-kinase substrate) phosphorylation (and other parameters of protein kinase $\mathrm{C}$ activation) in rat adipocytes, rat soleus muscle and BC3H-1 myocytes. Biochemical Journal 295 155-164.

Avignon A, Yamada K, Zhou X, Spencer B, Cardona O, Saba-Siddique S, Galloway L, Standaert ML \& Farese RV 1996 Chronic activation of protein kinase $\mathrm{C}$ in soleus muscles and other tissues of insulin-resistant type II diabetic Goto-Kakizaki (GK), obese/aged, and obese/Zucker rats. A mechanism for inhibiting glycogen synthesis. Diabetes 45 1396-1404.
Azpiazu I, Saltiel AR, DePaoli-Roach A \& Lawrence JC 1996 Regulation of both glycogen synthase and PHAS-1 in rat skeletal muscle involves mitogen-activated protein kinase-independent and rapamycin-sensitive pathways. Journal of Biological Chemistry 271 5033-5039.

Bradford MM 1976 A rapid and sensitive method for the quantitation of microgram quantities of protein utilizing the principle of protein dye binding. Analytical Biochemistry 72 248-254.

Brady MJ, Nairn AC \& Saltiel AR 1997 The regulation of glycogen synthase by protein phosphatase 1 in 3T3-L1 adipocytes. Evidence for a potential role for DARPP-32 in insulin action. Journal of Clinical Chemistry 272 29698-29703.

Buteau J, Roduit R, Susini S \& Prentki M 1999 Glucagon-like peptide-1 promotes DNA synthesis, activates phosphatidylinositol 3 kinase and increases transcription factor pancreatic and duodenal homeobox gene 1 (PDX-1) DNA binding activity in beta (INS-1)-cells. Diabetologia 42 856-864.

Buteau J, Foisy S, Rhodes CJ, Carpenter L, Biden TJ \& Prentki M 2001 Protein kinase $\mathrm{C} \zeta$ activation mediates glucagon-like peptide- 1 induced pancreatic $\beta$ cell proliferation. Diabetes $\mathbf{5 0}$ $2237-2243$.

Considine RV, Nyce MR, Allen LE, Morales LM, Triester S, Serrano J, Colberg J, Lanza-Jacoby S \& Caro JF 1995 Protein kinase C is increased in the liver of humans and rats with non-insulindependent diabetes mellitus: an alternation not due to hyperglycemia. Journal of Clinical Investigation 95 2938-2944.

Cross DAE, Alessi DR, Cohen P, Andjelkovich M \& Hemmings BA 1995 Inhibition of glycogen synthase kinase-3 by insulin mediated by protein kinase 3. Nature 378 785-789.

D'Alessio DA, Prigeon RL \& Ensinck JW 1995 Enteral enhancement of glucose disposition by both insulin-dependent and insulinindependent processes. A physiological role of glucagon-like peptide I. Diabetes 44 1433-1437.

Davies SP, Reddy H, Caivano M, Cohen P 2000 Specificity and mechanism of action of some commonly used protein kinase inhibitors. Biochemical Journal 351 95-105.

Delgado E, Luque MA, Alcántara A, Trapote MA, Clemente F, Galera C, Valverde I \& Villanueva-Peñacarrillo ML 1995 Glucagon-like peptide-1 binding to rat skeletal muscle. Peptides 16 225-229.

Dent P, Lavoinne A, Nakielny S, Caudwell FB, Watt P \& Cohen P 1990 The molecular mechanism by which insulin stimulates glycogen synthesis in mammalian skeletal muscle. Nature $\mathbf{3 4 8}$ 302-308.

Egan JM, Montrose-Rafizadeh CH, Wang Y, Bernier M \& Roth J 1994 Glucagon-like peptide-1(7-36)amide (GLP-1) enhances insulin-stimulated glucose metabolism in 3T3-L1 adipocytes: one of several potential extrapancreatic sites of GLP-1 action. Endocrinology 135 2070-2075.

Galera C, Clemente F, Alcántara A, Trapote MA, Perea A, López-Delgado MI, Villanueva-Peñacarrillo ML \& Valverde I 1996 Inositolphosphoglycans and diacylglycerol are possible mediators in the GLP-1(7-36)amide glycogenic effect in BC3H-1 myocytes. Cell Biochemistry and Function 14 43-48.

Gutniak M, Orskov C, Holst JJ, Ahrén B \& Efendic S 1992 Antidiabetogenic effects of glucagon-like peptide-1(7-36)amide in normal subjects and patients with diabetes mellitus. New England Journal of Medicine 326 1316-1322.

Hajduch E, Litherland GJ \& Hundal HS 2001 Protein kinase B (PKB/Akt) a key regulator of glucose transport? FEBS Letters 492 199-203.

Halse R, Rochford JJ, McCormack JG, Vandenheede JR, Hemmings BA \& Yeaman SJ 1999 Control of glycogen synthesis in cultured human muscle cells. Journal of Biological Chemistry 274 776-780.

Hurel SJ, Rochford JJ, Borthwick AC, Wells AM, Vandenheede JR, Tumbull DM \& Yeaman SJ 1996 Insulin action in cultured human myoblasts: contribution of different signalling pathways to regulation of glycogen synthesis. Biochemical Journal 320 871-877. 
Ishizuka T, Miura A, Kajita K, Yamada K, Wada H, Itaya S, Kanoh Y, Ishizawa M, Kimura M \& Yasuda K 1998 Alterations in insulin-induced postreceptor signaling in adipocytes of the Otsuka Long-Evans Tokushima fatty rat strain. Journal of Endocrinology 156 $1-13$.

Laemmli UK 1970 Cleavage of structural proteins during the assembly of the head of bacteriophage T4. Nature 227 680-685.

Lazar DF, Wiese RJ, Brady MJ, Mastick CC, Waters SB, Yamauchi K, Pessin JE, Cuatrecasas P \& Saltiel AR 1995 Mitogen-activated protein kinase kinase inhibition does not block the stimulation of glucose utilization by insulin. Journal of Biological Chemistry $\mathbf{2 7 0}$ 20801-20807.

Litherland GJ, Hajduch E \& Hundal HS 2001 Intracellular signalling mechanisms regulating glucose transport in insulin sensitive tissues. Molecular Membrane Biology 18 195-204.

Liu J \& Brautigan DL 2000 Insulin-stimulated phosphorylation of the protein phosphatase-1 striated muscle glycogen-targeting subunit and activation of glycogen synthase. Journal of Biological Chemistry 275 15940-15947.

Luque MA, González N, Márquez L, Acitores A, Redondo A, Morales M, Valverde I \& Villanueva-Peñacarrillo ML 2002 GLP-1 and glucose metabolism in human myocytes. Journal of Endocrinology $173465-473$.

Márquez L, Trapote MA, Luque MA, Valverde I \& VillanuevaPeñacarrillo ML 1998 Inositolphosphoglycans possibly mediate the effects of glucagon-like peptide-1(7-36)amide on rat liver and adipose tissue. Cellular Biochemistry and Function 16 51-56.

Mérida E, Delgado E, Molina LM, Villanueva-Peñacarrillo ML \& Valverde I 1993 Presence of glucagon and glucagon-like peptide-1(7-36)amide receptors in solubilized membranes of human adipose tissue. Journal of Clinical Endocrinology and Metabolism $\mathbf{7 7}$ $1654-1657$.

Montrose-Rafizadeh C, Avdonin P, Garant MJ, Rodgers BD, Kole S, Yang H, Levine MA, Schwindinger W \& Bernier M 1999 Pancreatic glucagon-like peptide-1 receptor couples to multiple $G$ proteins and activates mitogen-activated protein kinase pathways in Chinese hamster ovary cells. Endocrinology 140 1132-1140.

Morales M, López-Delgado MI, Alcántara A, Luque MA, Clemente F, Márquez L, Puente J, Viñambres C, Malaisse WJ, VillanuevaPeñacarrillo ML \& Valverde I 1997 Preserved GLP-1 effects upon glycogen synthase $a$ activity and glucose metabolism in isolated hepatocytes and skeletal muscle from diabetic rats. Diabetes $\mathbf{4 6}$ 1264-1269.

Moule SK, Edgell NJ, Welsh GI, Diggle TA, Foulstone EJ, Heesom KJ, Proud CG \& Dentom RM 1995 Multiple signalling pathways involved in the stimulation of fatty acid glycogen synthesis by insulin in rat epididymal fat cells. Biochemical Journal 311 595-601.

Moxham CM, Tabrizchi A, Davis RJ \& Malbon CC 1996 jun $\mathrm{N}$-terminal kinase mediates activation of skeletal muscle glycogen synthase by insulin in vivo. Journal of Biological Chemistry 271 30765-30773.

Oben J, Morgan L, Alarcón C, Mérida E \& Valverde I 1991 Effect of the entero-pancreatic hormones, gastric inhibitory polypeptide and glucagon-like peptide-1(7-36)amide, on fatty acid synthesis in explants of rat adipose tissue. Journal of Endocrinology 130 267-272.

O'Harte FP, Gray AM, Abdel-Wahab YH \& Flatt PR 1997 Effects of non-glycated and glycated glucagon-like peptide-1(7-36) amide on glucose metabolism in isolated mouse abdominal muscle. Peptides 18 $1327-1333$

Peak M, Rochford JJ, Borthwick AC, Yeaman SJ \& Agius L 1998 Signalling pathways involved in the stimulation of glycogen synthesis by insulin in rat hepatocytes. Diabetologia 41 16-25.

Perea A, Viñambres C, Clemente F, Villanueva-Peñacarrillo ML \& Valverde I 1997 GLP-1(7-36)amide effects on glucose transport and metabolism in rat adipose tissue. Hormone and Metabolic Research 9 417-421.
Pessin JE \& Saltiel AR 2000 Signalling pathway in insulin action: molecular targets of insulin resistance. Journal of Clinical Investigation 106 165-169.

Phung TL, Roncone A, De Mesy Jensen KL, Sparks CE \& Sparks JD 1997 Phosphoinositide 3-kinase activity is necessary for insulindependent inhibition of apolipoprotein B secretion by rat hepatocytes and localizes to the endoplasmic reticulum. Journal of Biological Chemistry 272 30693-30702.

Pugazhenthi S \& Khandelwal RL 1995 Regulation of glycogen synthase activation in isolated hepatocytes. Molecular and Cellular Biochemistry 149-150 95-101.

Ragolia L \& Begum N 1998 Protein phosphatase-1 and insulin action. Cellular Biochemistry 182 49-58.

Redondo A, Trigo MV, Acitores A, Valverde I \& VillanuevaPeñacarrillo ML 2003 Cell signalling of the GLP-1 action in rat liver. Molecular and Cellular Endocrinology 204 43-50.

Shepherd PR, Nave BT \& Siddle K 1995 Insulin stimulation of glycogen synthesis and glycogen synthase activity is blocked by wortmannin and rapamycin in 3T3-L1 adipocytes: evidence for the involvement of phosphoinositide 3-kinase and p70 ribosomal protein-S6 kinase. Biochemical Journal 305 25-28.

Thorens B 1992 Expression cloning of the pancreatic beta cell receptor for the gluco-incretin hormone glucagon-like peptide-1. PNAS $\mathbf{8 9}$ 8641-8645.

Trapote MA, Clemente F, Galera C, Morales M, Alcántara A, López-Delgado MI, Villanueva-Peñacarrillo ML \& Valverde I 1996 Inositolphosphoglycans implicated in the GLP-1(7-36)amide action in the liver. Journal of Endocrinological Investigation 19 114-118.

Ueki K, Yamamoto-Honda R, Kaburagi Y, Yamauchi T, Tobe K, Burgering BMT, Coffer PJ, Komuro I, Akanuma Y, Yazaki Y \& Kadowaki T 1998 Potential role of protein kinase B in insulininduced glucose transport, glycogen synthesis and protein synthesis. Journal of Biological Chemistry 273 5315-5322.

Valverde I, Mérida E, Delgado E, Trapote MA \& VillanuevaPeñacarrillo ML 1993 Presence and characterization of glucagonlike peptide-1(7-36) amide receptors in solubilized membranes of rat adipose tissue. Endocrinology 132 75-79.

Valverde I, Morales M, Clemente F, López-Delgado MI, Delgado E, Perea A \& Villanueva-Peñacarrillo ML 1994 Glucagon-like peptide-1: a potent glycogenic hormone. FEBS Letters 349 313-316.

Villanueva-Peñacarrillo ML, Alcántara A, Clemente F, Delgado E \& Valverde I 1994 Potent glycogenic effect of GLP-1 (7-36) amide in rat skeletal muscle. Diabetologia 37 1163-1166.

Villanueva-Peñacarrillo ML, Delgado E, Trapote MA, Alcántara AI, Clemente F, Luque MA, Perea A \& Valverde I 1995a Glucagonlike peptide-1 binding to rat hepatic membranes. Journal of Endocrinology 146 183-189.

Villanueva-Peñacarrillo ML, Delgado E, Vicent D, Mérida E, Alcántara AI \& Valverde I 1995b GLP-1(7-36)amide binding in skeletal muscle membranes from streptozotocin diabetic rats. Endocrine 3 685-687.

Villanueva-Peñacarrillo ML, Márquez L, González N, Díaz-Miguel M \& Valverde I 2001a Effect of GLP-1 on lipid metabolism in human adipocytes. Hormone and Metabolic Research 33 73-77.

Villanueva-Peñacarrillo ML, Puente J, Redondo A, Clemente F \& Valverde I $2001 b$ Effect of GLP-1 treatment on GLUT2 and GLUT4 expression in NIDDM and IDDM rats. Endocrine 15 241-248.

Wang Y, Kole HK, Montrose-Rafizadeh C, Perfetti R, Bernier M \& Egan JM 1997 Regulation of glucose transporters and hexose uptake in 3T3-L1 adipocytes: glucagon-like peptide-1 and insulin interactions. Journal of Molecular Endocrinology 19 241-248.

Wilkinson SE, Parker PJ \& Nixon JS 1993 Isoenzyme specificity of bisindolmaleymides, selective inhibitors of protein kinase C. Biochemical Journal 294 335-337. 
Yang H, Egan JM, Wang Y, Moyes D, Roth J, Montrose MH \& Montrose-Rafizadeh C 1998 GLP-1 action in L6 myotubes is via a receptor different from the pancreatic GLP-1 receptor. American Journal of Physiology 275 C675-C683.
Received in final form 13 November 2003

Accepted 14 November 2003 